\title{
Phytochemical screening and antioxidant activity of Epidendrum nocturnum
}

Fernando Mencias, Telmo Salazar, Marco Cerna

DOI. 10.21931/RB/2021.06.01.8

Abstract: The objective of this study was to evaluate the antioxidant capacity of Epidendrum nocturnum using the DPPH technique to determine the capacity for scavenging free radicals, as well as to identify secondary metabolites in ethanolic extracts of the previously mentioned species by phytochemical screening, with analysis of alkaloids, flavonoids, saponins, tannins, and triterpenes. The results determined in the phytochemical screening that the secondary metabolites were most present were flavonoids, tannins, and saponins; no alkaloids or triterpenes were found. In the analysis of antioxidant activity, Epidendrum nocturnun in the three extracts showed that with an average concentration of $3.50 \mathrm{ppm}$, it could inhibit 50\% of the free radicals present in the test solution.

Key words: Antioxidant, Epidendrum, DPPH, metabolites, screening.

\section{Introduction}

Orchids belong to the Orchidaceae family, one of the most numerous families with approximately 35,000 species and striking for their beautiful flowers ${ }^{1}$. In Ecuador, Endara and Jost $^{2}$ mention that there are 1707 endemic orchid species, and because of this, it is said that this family is considered the most diverse of vascular plants.

We will find several secondary metabolites within the orchids such as alkaloids, flavonoids, phenols, terpenoids, and phenanthrenes; these being complex substances used as active principles in the pharmaceutical industry, they have a pharmacological or physiological action on the body ${ }^{3}$.

Within the scientific field, interest in verifying the ethnobotanical uses of plants, or obtaining new compounds with pharmacological activity, especially with antioxidant action. Because Ecuador has a great diversity of orchids used in traditional medicine that still do not have a phytochemical screening, the lack of scientific studies that corroborate these applications is evident; with those mentioned above, it is essential since active principles can be obtained to replace synthetic compounds used in the pharmaceutical industry ${ }^{4}$.

\section{Materials and methods}

\section{Location and collection of the sample}

The collection was carried out in the "Orquideario de Sarina," located in the province of Pichincha, in the canton of Quito, in the parish of El Quinche.

The plant material selected for this study was $100 \mathrm{~g}$ of leaves; the leaves were cut with pruning scissors previously sterilized with $96 \%$ alcohol, placed in paper bags, and stored in plastic bags with a seam to avoid deterioration the samples.

\section{Obtaining the ethanolic extract}

To obtain the ethanolic extracts, a maceration was carried out according to the methodology described by Moreno and Jaramillo ${ }^{5}$, the process consisted of: taking $100 \mathrm{~g}$ of young leaves, it was crushed in a porcelain mortar of $80 \mathrm{~mm}$ in diameter, $70 \mathrm{~mL}$ of $96 \%$ ethanol and macerated in an amber flask for 8 days in complete darkness. It was then filtered to remove leaf residues and stored in the dark and kept under ambient conditions; all this was repeated three times, obtaining three similar extracts.

\section{Phytochemical screening}

Using the Miranda and Cuellar Manual qualitative technique, preliminary colorimetric tests were used, which are fast and straightforward for determining secondary metabolites. The presence of alkaloids (Draggendorf;), flavonoids (Shinoda), saponins (foam), tannins (Gelatin-Salt), and triterpenes (Liebermann-Burchard) were determined in the ethanolic extracts.

If opalescence $(+)$, turbidity $(++)$, or precipitate $(+++)$ is observed, it is considered that the sample contains the secondary metabolite; in all analyses, 96\% alcohol was used as a negative control.

\section{Test for alkaloids}

Following the methodology described by Carrera et $a L^{6}$, using the Draggendorf reagent, $3 \mathrm{~mL}$ of sample was placed in a test tube, then 3 drops of the draggendorf reagent were added, vigorously shaken, and waited for 30 minutes. Caffeine was used as a positive control.

\section{Test for flavonoids}

Following the methodology described by Ramos et al. ${ }^{7}$, using the Shinoda reagent; For which $3 \mathrm{~mL}$ of sample was placed in a test tube, then several magnesium filings were added, the test tubes were placed in a water bath at $60{ }^{\circ} \mathrm{C}$, then 3 drops of concentrated $\mathrm{HCl}$ were placed. Apple was used as a positive control.

\section{Test of saponins}

Following the methodology described by Moreno and Jaramillo ${ }^{5}$, using the foam test; for which $3 \mathrm{~mL}$ of sample was placed in a test tube, then $5 \mathrm{~mL}$ of distilled water was added and vigorously stirred for one minute. Quinoa was used as a positive control.

\section{Tannins test}

Following the methodology described by Sánchez and Ca$\|^{2} e^{8}$, using the Gelatine-Salt reagent, $3 \mathrm{~mL}$ of the sample was placed in a test tube, then $2 \mathrm{~mL}$ of reagent was added. Black tea was used as a positive control.

\section{Triterpenes test}

Following the methodology described by Carrera et $a L^{6}$, using the Liebermann-Burchard reagent; for which $3 \mathrm{~mL}$ of sample was placed in a test tube, then $1 \mathrm{~mL}$ of acetic anhydri- 
de was slowly added through the wall of the tube, and finally with caution, 2 drops of concentrated sulfuric acid were added. Calendula was used as a positive control.

\section{Evaluation of antioxidant activity}

For this test, the methodology of Noriega et al. ${ }^{9}$ was used for which a solution of 2,2-diphenyl-1-picrylhydracil DPPH was made. For each of the extracts, dilutions were prepared in different concentrations: $10 \mathrm{uL}, 50 \mathrm{uL}$, and $80 \mathrm{uL}$ in amber vials; it was completed with $96 \%$ alcohol obtaining a volume of $100 \mathrm{uL} ; 2.9 \mathrm{~mL}$ of DPPH was added to these dilutions until the final volume was $3 \mathrm{~mL}$, it was homogenized and stored in the dark for 30 minutes.

\section{Preparation of the DPPH solution}

24 hours before the analysis, $500 \mathrm{~mL}$ of DPPH was prepared in $96 \%$ ethanol, for which $19.70 \mathrm{mg}$ of DPPH was weighed, it was dissolved in $200 \mathrm{~mL}$ of drinking alcohol, then it was added to $500 \mathrm{~mL}$, this The solution was stored in an amber bottle wrapped in aluminum foil refrigerated at $4^{\circ} \mathrm{C}$, a technique described by Castañeda et $a l^{10}$.

\section{Vitamin C standard curve}

The standard was prepared by dissolving $20 \mathrm{mg}$ of ascorbic acid in $100 \mathrm{~mL}$ of ultrapure water as described by Noriega et al. ${ }^{9}$.

The concentration of vitamin C obtained was $0.2 \mathrm{mg} / \mathrm{mL}$ with which the following dilutions were made:

$100 \mathrm{uL}$ of vitamin $\mathrm{C}+0 \mathrm{uL}$ of pure water

$80 \mathrm{uL}$ of vitamin $\mathrm{C}+20 \mathrm{uL}$ of pure water

$60 \mathrm{uL}$ of vitamin $\mathrm{C}+40 \mathrm{uL}$ of pure water

$40 \mathrm{uL}$ of vitamin $\mathrm{C}+60 \mathrm{uL}$ of pure water

$20 \mathrm{uL}$ of vitamin $\mathrm{C}+80 \mathrm{uL}$ of pure water

0 uL of vitamin $C+100$ uL of pure water
The prepared solutions were placed in amber vials, and $2.9 \mathrm{~mL}$ of previously prepared DPPH was added to these, stirred, and remained in the dark for 30 minutes.

The prepared solutions were placed in $3 \mathrm{~mL}$ plastic cells to be analyzed in the spectrophotometer (JASCO V-730) at a wavelength of $517 \mathrm{~nm}$; the samples were analyzed to increase their concentration, each sample was analyzed in triplicate.

The calibration curve obtained in this investigation can be seen in figure 1 , which presents an $\mathrm{R}^{2}=0.9958$, being acceptable because it is close to 1 .

\section{Preparation of samples for analysis in the spectrophotometer}

From the extracts of each species under study and the following solutions were made:

$10 \mathrm{uL}$ of extract $+90 \mathrm{uL}$ of $96 \%$ ethanol

$50 \mathrm{uL}$ of extract $+50 \mathrm{uL}$ of $96 \%$ ethanol

$80 \mathrm{uL}$ of extract $+20 \mathrm{uL}$ of $96 \%$ ethanol

$100 \mathrm{uL}$ of alcohol $96 \%+2.9 \mathrm{~mL}$ DPPH

To analyze the samples in the spectrophotometer, the procedure used for vitamin $\mathrm{C}$ was replicated.

\section{Results and Discussion}

\section{Secondary metabolites identification}

The percentage of presence of secondary metabolites in the analyzed extracts of Epidendrum nocturnum were: flavonoids $100 \%$ in high concentration, tannins $100 \%$ in medium concentration, saponins $66.66 \%$ in low concentration, alkaloids and triterpenes $0 \%$, the concerning result the alkaloids contrasts with the study done by Sut et al. ${ }^{11}$, who found phenanthrenic alkaloids in species of the genus Epidendrum; This would indicate that the species collected has not had an external threat that induces the production of alkaloids, as explained by Farrán et al. ${ }^{12}$, see table 1 and table 2 .

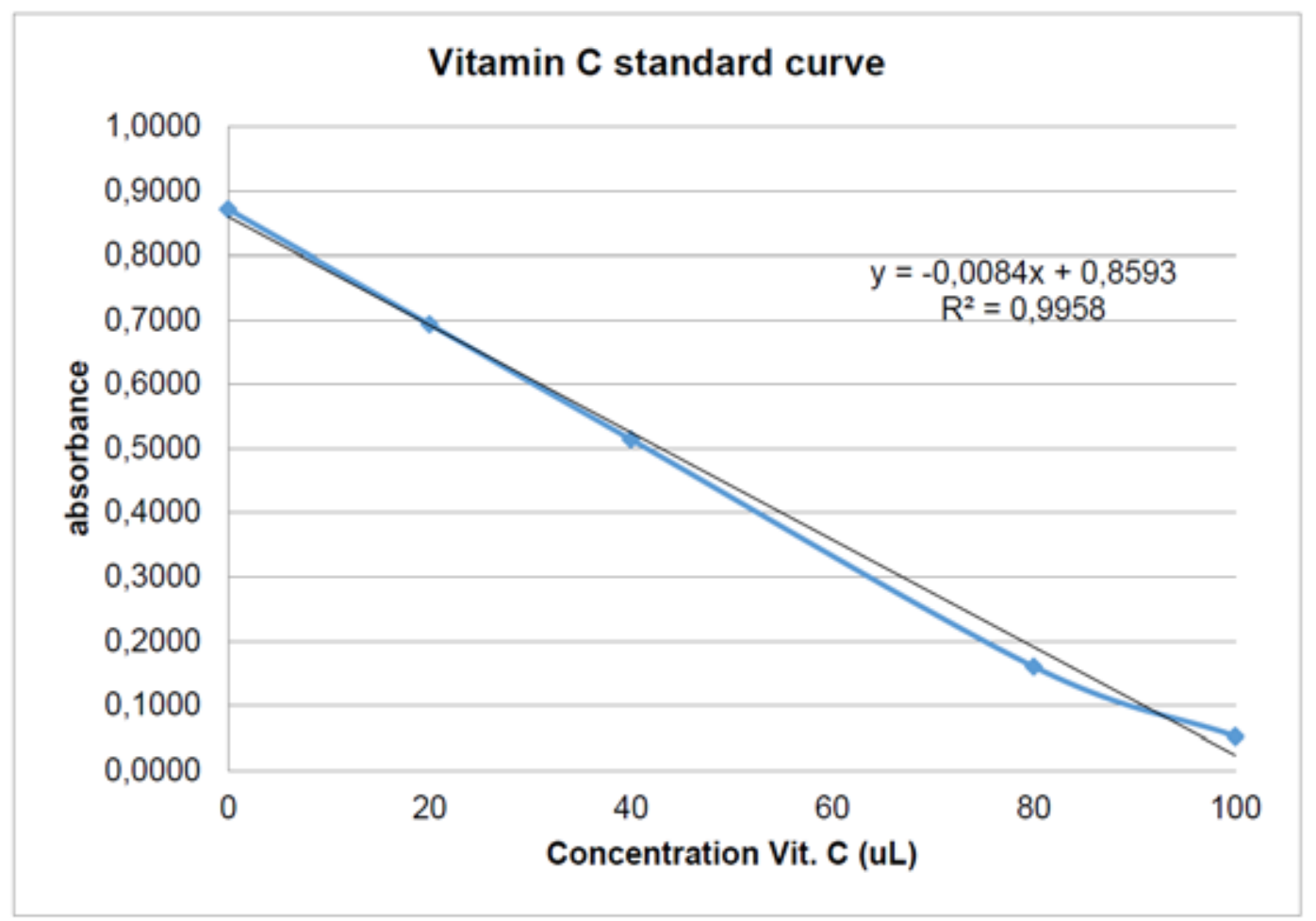

Note: Calibration curves obtained from Microsoft Excel 2013.

Figure 1. Vitamin C calibration curve. 


\section{Epidendrum nocturnum}

\begin{tabular}{|l|c|c|c|c|c|}
\hline Metabolites & ALKALOIDS & FLAVONOIDS & SAPONINS & TANNINS & TRITERPENES \\
\hline Secondary & - & ++ & + & + & - \\
\hline 1st extract & - & ++ & + & ++ & - \\
\hline 2nd extract & - & +++ & - & ++ & - \\
\hline 3rd extract & 0 & 100 & 66.66 & 100 & 0 \\
\hline
\end{tabular}

Note:Negative (-), little presence $(+)$, moderate presence $(++)$, high presence $(+++)$.

Table 1. Phytochemical screening of Epidendrum nocturnum.

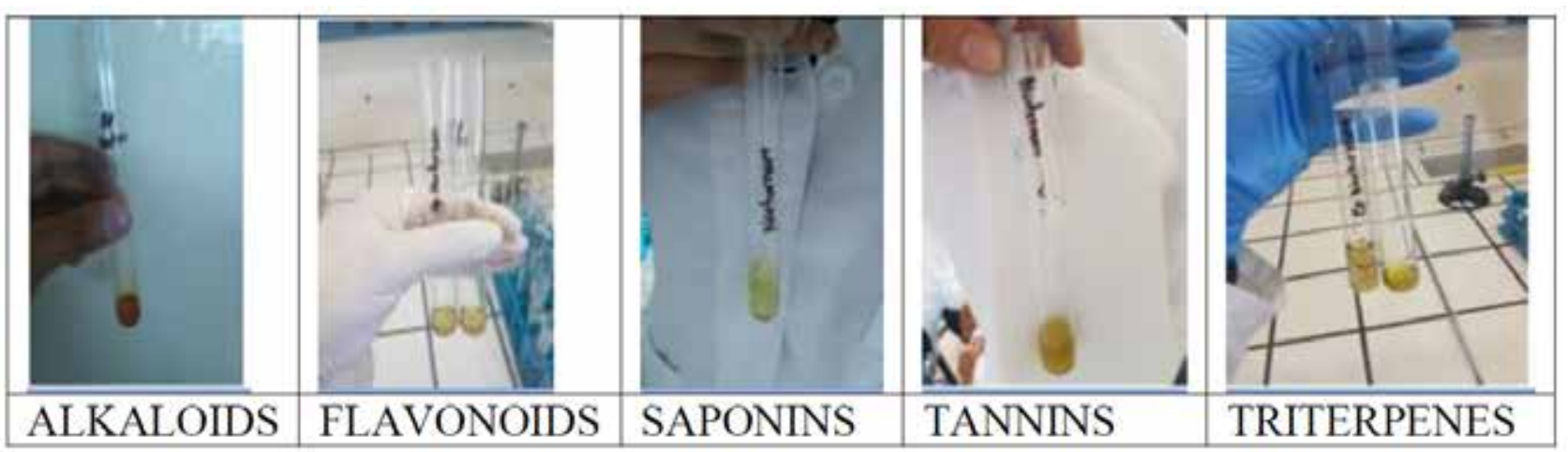

Table 2. Secondary metabolites analysis.

Note: Photographs of the tests carried out in the CIVABI UPS.

\section{Evaluation of antioxidant activity}

The extracts of E. nocturnum showed antioxidant capacity. The three extracts had similar results that, on average with a concentration of $3.50 \mathrm{ppm}$ they inhibited $50 \%$ of the DPPH free radicals. See figure 2 .

It was observed that the Epidendrum nocturnum species exceeded the antioxidant capacity of Prosthechea michuacana reported by González et al. ${ }^{13}$, which required 13.22 ppm to inhibit the \% IC50 of DPPH.

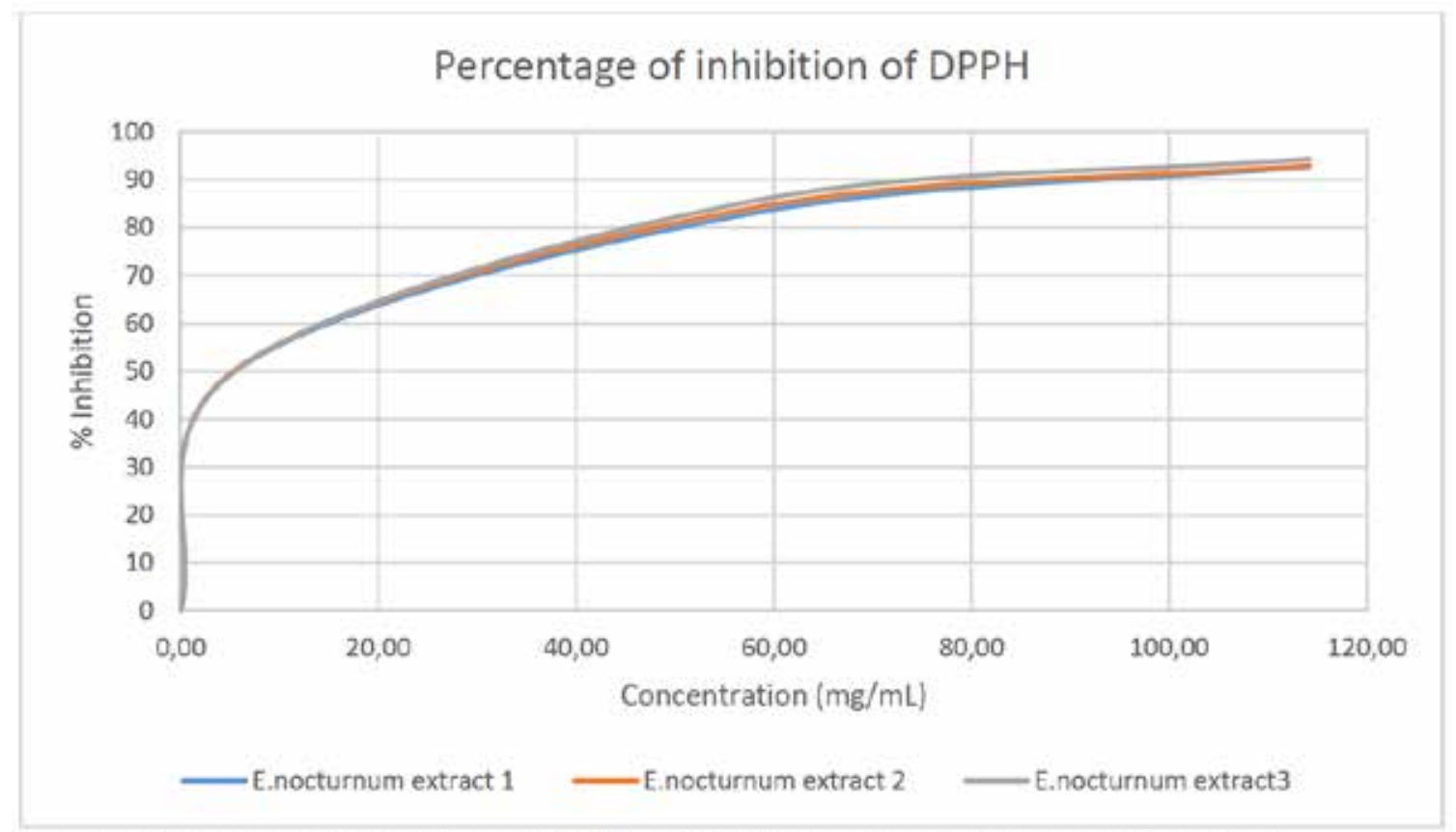

Note: Percentage of inhibition of DPPH of Epidendrum nocturmum obtained from Microsoft Excel 2013.

Figure 2. Percentage of inhibition of DPPH of Epidendrum nocturnum. 


\section{Conclusions}

The secondary metabolites present in Epidendrum nocturnum in $100 \%$ were flavonoids and tannins; in saponins, it was $66.66 \%$.

The antioxidant activity analysis showed in the 3 extracts Epidendrum nocturnum with only $3.5 \mathrm{ppm}$ inhibited $50 \%$ of DPPH free radicals.

Epidendrum nocturnum presented a significant antioxidant capacity and a high presence of flavonoids in its composition, confirming that this secondary metabolite contributes to these plants' antioxidant capacity.

\section{Bibliographic references}

1. F. María, Orquídeas, Buenos Aires: ALBATROS, 2011.

2. L. Endara y L. Jost, «Orchidaceae,» de Libro rojo de las plantas endémicas del Ecuador., Quito, Ecuador, Herbario QCA, Pontificia Universidad Católica del Ecuador, 2011.

3. M. Hossain, «Therapeutic orchids: traditional uses and recent advances-An overview,» Fitoterapia, vol. 82, pp. 102-140., 2011.

4. C. Rivas-Morales, M. Oranday-Cárdenas y M. Verde-Star, Investigación en plantas de importancia médica, Nuevo León: OmniaScience, 2016, pp. 105-121.

5. N. Moreno y B. Jaramillo, «Análisis fitoquímico preliminar de Pachira quinata (Jacq.) WS Alverson,» Boletín Semillas Ambientales, vol. 11, no 1, pp. 30-39, 2017.

6. G. Carrera, E. Benedito, T. Souza-Leal, C. Pedroso-De-Moraes y F. Gaspi, «Testes fitoquímicos em extratos foliares de Oeceoclades maculata Lindl.,» Revista Brasileira de Plantas Medicinais, vol. 16, no 4, pp. 938-944, 2014.
7. P. Ramos, G. Colareda, M. Rosella, S. Debenedetti, E. Spegazzini y A. Consolini, «Phytochemical profile and anti-inflammatory effect of the orchid Catasetum,» Latin American Journal of Pharmacy, vol. 31, no 1, pp. 62-67, 2012.

8. A. Sánchez y D. Calle, «Evaluación fitoquímica y determinación de flavonoides en hojas de Ficus benjamina L. Xilema,» Xilema, vol. 28, no 1, pp. 61-67, 2015.

9. P. Noriega, T. Mosquera, A. Baldisserotto, J. Abad, C. Aillon, D. Cabezas, J. Piedra, I. Coronel y S. Manfredini, «Chemical Composition and in-vitro biological activities of the essential oil from leaves of Peperomia inaequalifolia Ruiz \& Pav.,» American journal of essential oils and natural products, vol. 2, no 4, pp. 29-31, 2015.

10.B. Castañeda, E. Ramos y L. Ibáñez, «Evaluación de la capacidad antioxidante de siete plantas medicinales peruanas,» Horizonte médico, pp. 61-62, 2008.

11. S. Sut, F. Maggi y S. Dall'Acqua, «Bioactive secondary metabolites from orchids (Orchidaceae) 14.11 (2017): e1700172.,» Chemistry \& biodiversity, vol. 14, ํo 11, pp. 1-30, 2017.

12. A. Farrán, C. López, M. Pérez y M. D. Santa María, Quimica bioorganica y productos naturales, Madrid: UNED, 2017.

13. A. Neira, Aislamiento e identificación de los compuestos con actividad antioxidante del extracto de cloroformo de la orquídea comestible Prosthechea michuacana., México: Escuela Nacional de Ciencias Biológicas. Instituto Politecnico, 2009.

Received: 15 OCtober 2020

Accepted: 14 november 2020 